\title{
KLASIFIKASI TIPE SEL NORMAL/ABNORMAL BERDASARKAN CITRA PAP-SMEAR MENGGUNAKAN CONVOLUTIONAL NEURAL NETWORK
}

\author{
Muhamad Fathurahman ${ }^{12}$, Rachmadhani Ajeng Nurmufthi ${ }^{1}$, Elan Suherlan ${ }^{12}$ \\ ${ }^{1}$ Program Studi Teknik Informatika, Fakultas Teknologi Informasi, Universitas YARSI, Jakarta \\ ${ }^{2}$ Lab. Komputasi Cerdas, Fakultas Teknologi Informasi, Universitas YARSI, Jakarta
}

E-mail: muhammad.fathurrachman@yarsi.ac.id, ajengmufthi@gmail.com, elan.suherlan@yarsi.ac.id

\begin{abstract}
The classification of cell types plays an essential role in monitoring the growth of cancer cells. One of the methods to determine the cancer type is to analyze the pap-smear images manually. Nevertheless, the manual analysis of pap-smear images by the expert has several limitations, such as time-consuming and prone to misdiagnosis. For reducing the risks, it requires the automatic classification of cell types based on pap-smear images. This study utilizes the convolutional neural network $(\mathrm{CNN})$ architectures to automatically classify the cell type into two-class categories (normal/abnormal) based on three features. These features, such as the local binary pattern, gray level co-occurrence matrix, and shape features, are extracted from pap-smear images. This study shows the performance of CNN achieved the maximum accuracy of $99.98 \%, 100.0 \%, 99.78 \%$ in training, validation, and testing data. Our approach also outperforms the performance of the baseline methods.
\end{abstract}

Keywords : CNN, Classification, Cell, Neural Network, Pap-smear

\begin{abstract}
Abstrak
Klasifikasi jenis sel memainkan peranan penting dalam memantau pertumbuhan sel kanker. Salah satu metode untuk menentukan jenis kanker adalah dengan menganalisis secara manual gambar pap-smear. Namun demikian, analisis manual gambar pap-smear oleh ahli memiliki beberapa keterbatasan seperti memakan waktu lama dan rentan terhadap kesalahan diagnosis. Untuk mengurangi risiko pembatasan seperti di atas, klasifikasi otomatis tipe sel diperlukan. Penelitian ini memanfaatkan arsitektur convolutional neural network $(\mathrm{CNN})$ untuk secara otomatis mengklasifikasikan tipe sel ke dalam kategori dua kelas (normal / abnormal) berdasarkan tiga fitur berbeda termasuk local binary pattern, gray level co-occurence Matrix, dan fitur bentuk (shape feature). Penelitian ini menunjukkan bahwa, kinerja CNN mencapai akurasi maksimum 99,98\%, $100,0 \%$, 99,78\% dalam data pelatihan, validasi dan pengujian. Selain itu, pendekatan yang digunakan juga mengungguli kinerja dari metode umum lainnya.
\end{abstract}

Kata Kunci : CNN, Klasifikasi, Sel, Neural Network, Pap-smear 


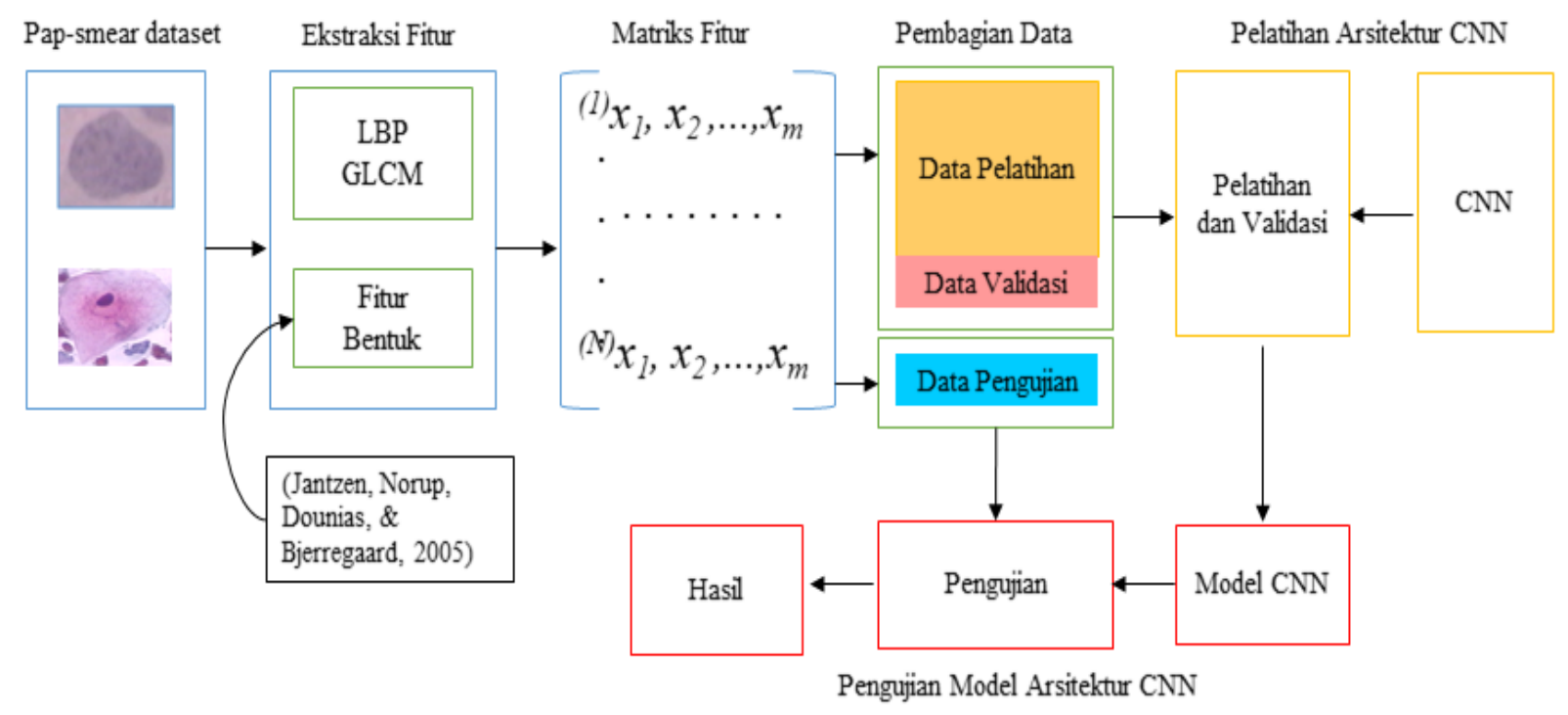

Gambar 1. Desain Eksperimen

\section{PENDAHULUAN}

Klasifikasi jenis sel memiliki peranan penting dalam memantau perkembangan penyakit kanker (Jantzen \& Dounias, 2006). Salah satu metode yang digunakan untuk melihat perkembangan sel adalah dengan menganalisis citra-pap smear. Citra papsmear adalah gambar pengamatan sel tunggal $d i$ bawah mikroskop yang diproses menggunakan metode pewarnaan Pa-panicolau untuk mendeteksi tahapan suatu penyakit, salah satunya adalah kanker (Jantzen \& Dounias, 2006). Namun, pemeriksaan secara manual memiliki beberapa kelemahan diantaranya adalah membutuhkan waktu yang lama (Ampazis, Dounias, \& Jantzen, 2010), dan dapat terjadi kesalahan pada saat analisis karena berdasarkan pada pengalaman pakar. Untuk mengurangi resiko dari kesalahan diatas, sistem klasifikasi jenis sel pada citra sel tunggal pap-smear dibutuhkan.

Sejumlah penelitian sistem klasifikasi jenis sel tunggal secara otomatis telah banyak dilakukan dengan menggunakan algoritma pembelajaran mesin khususnya pada tahapan klasifikasi. Algoritma yang telah digunakan adalah neural network (Ampazis dkk., 2010), (Devi, Ravi, Vaishnavi, \& Punitha, 2016), least square support vector machine, multi layer perceptron, random forest, bayesian, dan ensemble (Bora, Chowdhury, Mahanta, Kundu, \& Das, 2017), linear discriminant analysis, $k$-nearest neighbour, (Chankong, TheeraUmpon, \& Auephanwiriyakul, 2014). Klasifikasi citra sel tunggal pap-smear sulit dilakukan karena citra sel tunggal pap-smear terdapat overlapped-cell (citra sel tunggal yang tumpang tindih) dan dimensi gambar yang besar sehingga membutuhkan waktu komputasi yang lebih lama. Untuk menangani masalah di atas, sebelum melakukan tahapan klasifikasi, dilakukan alih bentuk (transformation) pada citra sel tunggal pap-smear yang disebut dengan ekstraksi fitur. Ekstraksi fitur dilakukan untuk memperoleh informasi relevan dari citra sel tunggal pap-smear dalam bentuk beberapa nilai numerik sebelum diproses oleh algoritma klasifikasi. Pada penelitian Bora dkk (Bora dkk., 2017), fitur bentuk (shape features), fitur tekstur dan ripplet descriptor digunakan sebagai dasar dalam mengklasifikasikan jenis sel tunggal. Penelitian (Bora dkk., 2017) mendapatkan nilai akurasi sebesar $96.51 \%$. Pada penelitian Chankong dkk (Chankong dkk., 2014), klasifikasi sel tunggal dilakukan berdasarkan fitur bentuk yang diperoleh dari hasil segmentasi citra sel tunggal menggunakan fuzzy c-means. Nilai akurasi yang didapatkan oleh (Chankong dkk, 2014) adalah 99.27\%. Selain itu, pendekatan multi-feature fussion berdasarkan fitur gray level co-occurence matrix (GLCM), fitur bentuk, dan fitur pola biner (local binary pattern) menggunakan deep belief network (DBN) menghasilkan nilai akurasi maksimal $97.35 \%$ (Muhamad, Wasito, Mufidah, \& Ghaisani, 2018). Penelitian sebelumnya lebih menekankan pada proses ekstraksi fitur dan alih bentuk fitur untuk meningkatkan akurasi klasifikasi citra sel tunggal. Oleh karena itu penelitian ini mengusulkan metode klasifikasi berdasarkan fitur GLCM, LPB dan fitur bentuk (shape feature) yang dialih bentukan (transformasi) melalui arsitektur convolutional neural network (CNN). Penelitian ini bertujuan 
untuk mengevaluasi pengaruh representasi fitur dari proses alih bentuk menggunakan arsitektur CNN terhadap nilai akurasi dari klasifikasi citra sel tunggal pap-smear.

Sistematika penulisan artikel ini disusun sebagai berikut. Bagian dua membahas tentang kerangka eksperimen yang digunakan pada penelitian ini mencakup dataset, metode ekstraksi fitur dan metode evaluasi. Bagian tiga membahas mengenai hasil eksperimen. Kesimpulan dan rencana kerja selanjutnya diberikan pada bagian empat.

\section{METODE DAN DATASET}

\subsection{Desain Eksperimen}

Alur desain eksperimen dapat dilihat pada Gambar 1. Tahapan pertama sebelum melakukan klasifikasi adalah melakukan ekstrasi fitur pada citra sel tunggal. Metode ekstraksi fitur yang digunakan pada penelitian ini adalah LBP dan GLCM serta fitur bentuk yang didapatkan dari penelitian (Jantzen dkk., 2005). Rincian fitur dapat dilihat pada Tabel 1 di bawah ini:

Tabel 1. Hasil ekstraksi fitur

\begin{tabular}{ll}
\hline Jenis Fitur & Jumlah Fitur \\
\hline LBP & 59 \\
GLCM & 4 \\
Fitur Bentuk & 20 \\
Total & 83 \\
\hline
\end{tabular}

Hasil ekstraksi fitur dari setiap citra sel tunggal dihimpun menjadi sebuah dataset. dataset ini dibagi menjadi tiga bagian subset yang terdiri dari data pelatihan, data validasi dan data pengujian. Metode pembagian data menggunakan metode hold-out crossvalidation. Data pelatihan dan validasi digunakan untuk melakukan pelatihan dan mencari konfigurasi yang tepat pada arsitektur CNN sedangkan data pengujian digunakan untuk mengukur peforma dari arsitektur CNN yang telah didapatkan pada proses pelatihan. Proporsi pembagian data pelatihan $90 \%$, validasi dan pengujian $5 \%$. Jumlah dari setiap proporsi dapat dilihat pada Tabel 2 di bawah ini.

Tabel 2. Proporsi pembagian data pelatihan, validasi dan

\begin{tabular}{lll}
\multicolumn{2}{c}{ pengujian } & \\
\hline Pelatihan & Validasi & Pengujian \\
\hline 827 & 44 & 46 \\
\hline
\end{tabular}

Adapun arsitektur CNN yang diujikan pada penelitian ini adalah sebanyak tiga arsitektur yang memiliki jumlah layer dan jumlah hidden unit yang berbeda. Parameter ini dapat dilihat pada Tabel 5 di bawah ini.
Tabel 3. Arsitektur CNN

\begin{tabular}{lcl}
\hline Arsitektur & Jumlah Layer & \multicolumn{1}{c}{ Unit Layer } \\
\hline $\mathrm{CNN}_{1}$ & 2 & $(256,128)$ \\
$\mathrm{CNN}_{2}$ & 3 & $(256,128,64)$ \\
$\mathrm{CNN}_{3}$ & 4 & $(256,128,64,32)$ \\
\hline
\end{tabular}

Parameter lain yang diatur pada arsitektur CNN adalah nilai batch size $=20$, drop out $=0.5$, kernel size $=2$, stride $=2$, epoch $=10$, dan regularization $=0.0001$. Selanjutnya, arsitektur CNN yang telah dibangun sesuai dengan parameter di atas, dilatih menggunakan data pelatihan dan dievaluasi menggunakan data validasi dan pengujian. Eksperimen pelatihan dan evaluasi dari setiap arsitektur CNN dilakukan sebanyak 30 kali kemudian dihitung nilai rata-rata akurasi yang didapatkan.

\subsection{Dataset}

Dataset yang digunakan pada penelitian ini adalah Herlev dataset yang bersumber dari (Jantzen \& Dounias, 2006). Dataset ini berisi citra sel tunggal pap-smear berjumlah 917 citra yang terdiri dari tujuh jenis sel tunggal yang berbeda. Tujuh jenis sel tunggal yang dapat dikategorikan menjadi dua kelas

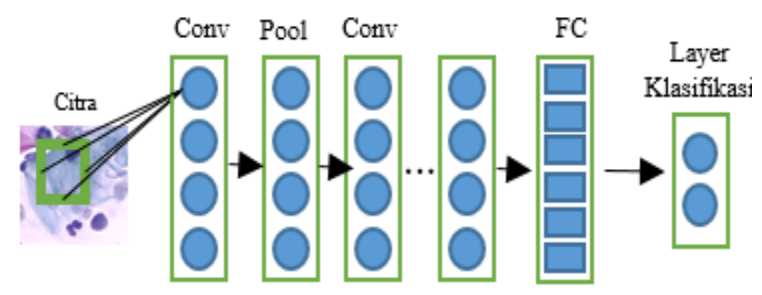

Gambar 2. Arsitektur CNN

utama yaitu normal dan abnormal (Jantzen \& Dounias, 2006). Jumlah distribusi dari setiap kelas dapat dilihat pada tabel 1 di bawah ini.

\begin{tabular}{|c|c|c|c|}
\hline No & Jenis Sel & Jumlah & Kategori \\
\hline 1 & $\begin{array}{l}\text { Superficial squamous } \\
\text { epithelial }\end{array}$ & 74 & \multirow{3}{*}{$\begin{array}{c}242 \\
\text { Normal }\end{array}$} \\
\hline 2 & $\begin{array}{l}\text { Intermediate squamous } \\
\text { epithelial }\end{array}$ & 70 & \\
\hline 3 & Columnar epithelial & 98 & \\
\hline 4 & $\begin{array}{l}\text { Mild squamous non- } \\
\text { keratinizing dysplasia }\end{array}$ & 182 & \multirow{4}{*}{$\begin{array}{c}675 \\
\text { Abnormal }\end{array}$} \\
\hline 5 & $\begin{array}{l}\text { Moderate squamous non- } \\
\text { keratinizing dysplasia }\end{array}$ & 146 & \\
\hline 6 & $\begin{array}{l}\text { Severe squamous non- } \\
\text { keratinizing dysplasia }\end{array}$ & 197 & \\
\hline 7 & $\begin{array}{l}\text { Squamous cell carcinoma in } \\
\text { situ intermediate }\end{array}$ & 150 & \\
\hline
\end{tabular}

\subsection{Convolutional Neural Network}


Convolutional neural network merupakan pengembangan dari multilayer neural network yang secara khusus untuk menerima masukan berupa citra dua dimensi (2D) (Lecun, Bottou, Bengio, \& Haffner, 1998). Secara umum, CNN terbagi menjadi tiga layer (lapisan) yaitu convolutional layer, pooling layer dan fully-connected layer (FC). Convolutional layer menerima sebuah citra dan melakukan komputasi menggunakan sebuah filter. Hasil komputasi dari Convolutional Layer adalah sebuah feature maps.

Selanjutnya, feature map dijadikan sebagai masukan pada pooling layer. Pooling layer bertujuan melakukan penyusutan dimensi pada feature map. Hasil pemrosesan pada pooling layer akan diproses pada convolutional layer berikutnya. Setelah melakukan komputasi hingga pada convolutional dan pooling layer terakhir. Keluaran dari convolutional dan pooling layer dimasukkan pada fully-connected layer. Lapisan pada fully connected layer memiliki mekanisme yang sama dengan arsitektur multilayer perceptron, bobot yang terhubung pada setiap layer diperbaharui menggunakan algoritma gradient-descent (Zhou, 2018). Ilustrasi arsitektur CNN dapat dilihat pada Gambar 2.s

\subsection{Fitur Bentuk (Shape Feature)}

Pada penelitian ini, fitur bentuk yang digunakan merujuk pada penelitian yang dilakukan oleh (Jantzen et al., 2005). Jantzen dkk, melakukan ekstraksi fitur dengan mengukur 14 atribut pada sel dan inti sel (nucleus) yang terdapat pada citra papsmear sel tunggal yang telah dilakukan proses segmentasi (Jantzen dkk., 2005). Atribut yang diukur pada citra pap-smear sel tunggal tersegmentasi dapat dilihat pada Tabel 2 di bawah ini

Tabel 5. Fitur Bentuk (Jantzen dkk., 2005)

\begin{tabular}{ll}
\hline & Tabel 5. Fitur Bentuk (Jantzen dkk., 2005) \\
\hline 1 & Nama Atribut \\
2 & N Area \\
3 & C Area \\
4 & N/C Ratio \\
5 & N Brightness \\
6 & C Brightness \\
7 & N Shortest diameter \\
8 & N longest diameter \\
9 & N elongation \\
10 & N roundness \\
11 & C shortest diameter \\
12 & C longest diameter \\
13 & C elongation \\
14 & C roundness \\
15 & C perimeter \\
16 & N relative position
\end{tabular}


$\mu$ adalah mean dan $\sigma$ adalah variance (Haralick \& Shanmugam, 1973).

\subsection{Metode Evaluasi}

Metode evaluasi yang digunakan pada penelitian ini adalah menghitung nilai akurasi dari hasil klasifikasi berdasarkan formula (7) di bawah ini:

$$
\text { Akurasi }=\frac{T P+T N}{K}
$$

TP adalah nilai citra sel tunggal abnormal yang diklasifikasikan sebagai citra sel tunggal abnormal. TN adalah citra sel tunggal normal yang diklasifikasikan sebagai citra sel tunggal normal. K adalah jumlah citra sel tunggal.

\section{HASIL DAN DISKUSI}

Penggunaan arsitektur CNN untuk klasifikasi melibatkan banyak parameter seperti jumlah layer, hidden unit dan epoch yang dapat mempengaruhi nilai akurasi. Oleh karena bagian ini membahas hasil dari eksprimen penggunaan arsitektur CNN berdasarkan konfigurasi parameter yang berbeda. Pada penelitian ini, dilakukan dua tahap eksperimen yang bertujuan untuk mencari konfigurasi parameter terbaik arsitektur CNN dalam melakukan klasifikasi. Eksperimen pertama bertujuan untuk melihat pengaruh perbedaan jumlah layer dan hidden unit terhadap nilai akurasi dari klasifikasi kelas normal dan abnormal pada citra sel tunggal pap-smear. Eksperimen kedua bertujuan untuk melihat pengaruh nilai epoch pada arsitektur terbaik berdasaran eksperimen pertama. Arsitektur CNN yang digunakan pada kedua eksperimen ini merujuk pada Tabel 3 di atas.

\subsection{Hasil Eksperimen 1}

Hasil eksperimen 1 dapat dilihat pada Tabel 6 di bawah ini.

\begin{tabular}{cccc} 
& \multicolumn{3}{c}{ Tabel 1. Hasil Eksperimen 1 } \\
\cline { 2 - 4 } Arsitektur & \multicolumn{3}{c}{ Akurasi } \\
& $\begin{array}{c}\text { Data } \\
\text { Pelatihan }\end{array}$ & $\begin{array}{c}\text { Data } \\
\text { Validasi }\end{array}$ & $\begin{array}{c}\text { Data } \\
\text { Pengujian }\end{array}$ \\
\hline $\mathrm{CNN}_{1}$ & $98.40 \%$ & $97.72 \%$ & $\mathbf{9 8 . 0 4 \%}$ \\
$\mathrm{CNN}_{2}$ & $98.52 \%$ & $97.95 \%$ & $\mathbf{9 9 . 1 3 \%}$ \\
$\mathrm{CNN}_{3}$ & $98.60 \%$ & $96.13 \%$ & $97.60 \%$ \\
\hline
\end{tabular}

berdasarkan hasil eksperimen 1 , arsitektur $\mathrm{CNN}_{2}$ memiliki nilai akurasi pada data pengujian yang lebih tinggi yaitu $99.13 \%$ diikuti oleh $\mathrm{CNN}_{1} 98.04 \%$ dan $\mathrm{CNN}_{3}$ sebesar $97.60 \%$. Walaupun $\mathrm{CNN}_{3}$ memiliki nilai akurasi pada data pelatihan yang lebih besar dari $\mathrm{CNN}_{1}$ dan $\mathrm{CNN}_{2}$, hal ini tidak menjadi pertimbangan karena, data pelatihan sudah dikenali pada proses pelatihan sehingga cenderung memiliki nilai akurasi yang selalu tinggi. Adapun nilai akurasi pada data validasi dan penggujian dapat menggambarkan kemampuan generalisasi dari arsitektur CNN yaitu kemampuan mengklasifikasikan secara benar data yang tidak terlibat pada proses pelatihan. Pada eksperimen ini, terlihat bahwa $\mathrm{CNN}_{2}$ dan $\mathrm{CNN}_{1}$ memiliki kemampuan generalisasi yang baik.

\subsection{Hasil Eksperimen 2}

Eksperimen ini bertujuan untuk melihat pengaruh nilai epoch terhadap nilai akurasi hasil klasifikasi pada arsitektur $\mathrm{CNN}_{1}$ dan $\mathrm{CNN}_{2}$. Nilai epoch yang diuji adalah [10,100,200,300]. Hasil dari eksperimen 2 dapat dilihat pada Tabel $7 \mathrm{di}$ bawah ini. 
Tabel 2. Hasil eksperimen 2

\begin{tabular}{ccccc}
\hline \multirow{2}{*}{$\begin{array}{c}\text { Arsitektu } \\
\mathbf{r}\end{array}$} & $\begin{array}{c}\text { Epoc } \\
\mathbf{h}\end{array}$ & $\begin{array}{c}\text { Data } \\
\text { Pelatiha } \\
\mathbf{n}\end{array}$ & $\begin{array}{c}\text { Data } \\
\text { Validas } \\
\mathbf{i}\end{array}$ & $\begin{array}{c}\text { Data } \\
\text { Pengujia } \\
\mathbf{n}\end{array}$ \\
\hline \multirow{3}{*}{$\mathrm{CNN}_{1}$} & 10 & $98.40 \%$ & $97.72 \%$ & $98.04 \%$ \\
& 100 & $100.0 \%$ & $100.0 \%$ & $99.34 \%$ \\
& 200 & $99.98 \%$ & $99.77 \%$ & $\mathbf{9 9 . 5 6 \%}$ \\
& 300 & $100.0 \%$ & $99.70 \%$ & $99.56 \%$ \\
\hline \multirow{2}{*}{$\mathrm{CNN}_{2}$} & 10 & $98.52 \%$ & $97.95 \%$ & $99.13 \%$ \\
& 100 & $99.96 \%$ & $99.31 \%$ & $99.56 \%$ \\
& 200 & $99.98 \%$ & $100.0 \%$ & $\mathbf{9 9 . 7 8 \%}$ \\
& 300 & $100.0 \%$ & $99.09 \%$ & $99.34 \%$ \\
\hline
\end{tabular}

Berdasarkan hasil pada Tabel 7 , terjadi peningkatan nilai akurasi pada data pengujian ketika nilai epoch ditingkatkan dari 10-200 pada arsitektur $\mathrm{CNN}_{1}$ dan $\mathrm{CNN}_{2}$. $\mathrm{CNN}_{2}$ pada epoch 200 , memiliki nilai akurasi pada data pengujian yaitu $99.76 \%$ diikuti oleh $\mathrm{CNN}_{1}$ sebesar $99.56 \%$. Adapun ketika nilai epoch ditingkatkan pada nilai 300 , nilai akurasi pada arsitektur $\mathrm{CNN}_{2}$ cenderung menurun, hal ini dapat terjadi karena pendekatan gradient descent yang diadopsi oleh algoritma CNN dapat terjebak pada solusi local minima.

\subsection{Perbandingan dengan Metode Lain}

Pada bagian ini, peforma CNN berdasarkan fitur LPB, GLCM dan fitur bentuk (Shape Features) akan dibandingkan dengan beberapa penelitian sebelumnya yang dilakukan oleh (Bora dkk., 2017) dan (Muhamad dkk., 2018) yang dapat dilihat pada grafik di bawah ini.

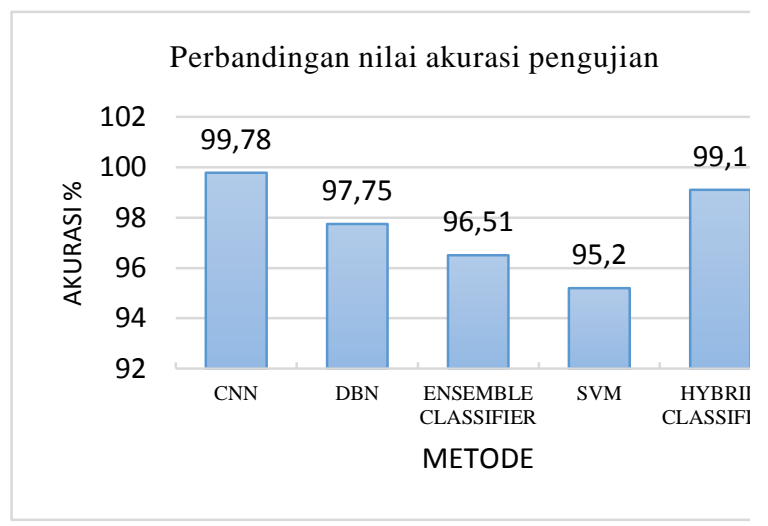

Gambar 1. Perbandingan akurasi metode CNN dengan metode lain

Pada Gambar 3 di atas, $\mathrm{CNN}_{2}$ berdasarkan fitur bentuk, GLCM dan LBP, memiliki hasil akurasi yang lebih baik dibanding dengan metode DBN oleh (Muhamad dkk., 2018) dan metode Ensemble, SVM dan Hybrid Classifier oleh (Bora dkk., 2017).

\section{KESIMPULAN DAN RENCANA SELANJUTNYA}

Penelitian ini mencoba untuk mengevaluasi peforma arsitektur CNN berdasarkan fitur bentuk, GLCM dan LBP dengan mengukur nilai akurasi dari hasil klasifikasi. Berdasarkan ekperimen yang dilakukan, arsitektur $\mathrm{CNN}_{2}$ memperoleh nilai akurasi pada data pengujian sebesar $99.78 \%$ dengan jumlah layer $=3$, hidden unit $=[256,128,64]$ dan epoch $=200$. Selain itu kemampuan arsitektur $\mathrm{CNN}_{2}$ memiliki kemampuan generalisasi yang baik, hal ini dapat dilihat dari perbandingan nilai akurasi pada data pelatihan, validasi dan pengujian yang dilakukan pada eksperimen 1 dan 2 memiliki selisih yang kecil (low variance). Perbandingan dengan penelitian sebelumnya, CNN memiliki nilai akurasi yang lebih baik dibandingkan dengan metode yang diusulkan oleh (Bora dkk., 2017) dan (Muhamad dkk., 2018).

Pada rencana selanjutnya, arsitektur CNN yang lebih kompleks akan digunakan untuk melakukan klasifikasi terhadap tujuh jenis sel berbeda berdasarkan skema transfer-learning. Arsitektur CNN dengan skema transfer-learning yang akan digunakan meliputi RestNet, GoogleNet, Inception, AlexNet.

\section{DAFTAR PUSTAKA}

Ampazis, N., Dounias, G., \& Jantzen, J. (2010). PapSmear Classification Using Efficient Second Order Neural Network Training Algorithms, 230-245. https://doi.org/10.1007/978-3-540-24674-9_25

Bora, K., Chowdhury, M., Mahanta, L. B., Kundu, M. K., \& Das, A. K. (2017). Automated classification of Pap smear images to detect cervical dysplasia. Computer Methods and Programs in Biomedicine, 138 , $31-47$. https://doi.org/10.1016/j.cmpb.2016.10.001

Chankong, T., Theera-Umpon, N., \& Auephanwiriyakul, S. (2014). Automatic cervical cell segmentation and classification in Pap smears. Computer Methods and Programs in Biomedicine, 113(2), 539-556.

https://doi.org/10.1016/j.cmpb.2013.12.012

Devi, M. A., Ravi, S., Vaishnavi, J., \& Punitha, S. (2016). Classification of Cervical Cancer Using Artificial Neural Networks. Procedia Computer Science, 89, 465-472.

https://doi.org/10.1016/j.procs.2016.06.105

Haralick, R. M., \& Shanmugam, K. (1973). Textural Features for Image Classification. IEEE TRANSACTIONS ON SYSTEMS, MAN, AND CYBERNETICS, SMC-3(6), 610-621. https://doi.org/10.1109/TSMC.1973.4309314

Jantzen, J., \& Dounias, G. (2006). Analysis of Pap-Smear 
Image Data. Proceedings of the Nature-Inspired Smart Information Systems 2nd Annual Symposium, 10.

Jantzen, J., Norup, J., Dounias, G., \& Bjerregaard, B. (2005). Pap-smear Benchmark Data For Pattern Classification. Proceedings of NiSIS 2005: Nature Inspired Smart Information Systems (NiSIS), 1-9.

Lecun, Y., Bottou, L., Bengio, Y., \& Haffner, P. (1998). Gradient-Based Learning Applied to Document Recognition. Proc. OF THE IEEE. Retrieved from $\mathrm{http}$ ://ieeexplore.iee.org/document/726791/\#fulltext-section

Liu, N., \& Kan, J. ming. (2016). Improved deep belief networks and multi-feature fusion for leaf identification. Neurocomputing, 216, 460-467. https://doi.org/10.1016/j.neucom.2016.08.005

Muhamad, F., Wasito, I., Mufidah, R., \& Ghaisani, F. D. (2018). Multi feature fusion using deep belief network for automatic pap-smear cell image classification. Proceedings - 2017 International Conference on Computer, Control, Informatics and Its Applications: Emerging Trends In Computational Science and Engineering, IC3INA 2017, 2018-Jапиа, 18-22. https://doi.org/10.1109/IC3INA.2017.8251733

Zhou, X. (2018). Understanding the Convolutional Neural Networks with Gradient Descent and Backpropagation. Journal of Physics: Conference Series, 1004(1). https://doi.org/10.1088/1742$6596 / 1004 / 1 / 012028$ 